\title{
The BRICS and Other Emerging Power Alliances and Multilateral Organizations in the Asia-Pacific and the Global South: Challenges for the European Union and Its View on Multilateralism*
}

\author{
STEPHAN KEUKELEIRE ${ }^{1}$ and BAS HOOIJMAAIJERS ${ }^{2}$ \\ ${ }^{1} \mathrm{KU}$ Leuven/College of Europe. ${ }^{2}$ Shanghai Jiao Tong University/KU Leuven
}

\begin{abstract}
Over the past decade the BRICS (Brazil, Russia, India, China and South Africa) and other emerging power alliances (such as BASIC [Brazil, South Africa, India and China] and IBSA [India, Brazil, South Africa]), as well as multilateral organizations in the Asia-Pacific and the global south, have become increasingly important players on the world stage. None of the variations on Asian regionalism and emerging power alliances is in itself very influential. Taken together, however, they are not inconsequential for the European Union (EU) and its position on multilateralism. Their views on multilateralism differ from the EU's vision with regard to contents and methodology. Problematic for the EU is that their views not only structure the relations between the emerging powers themselves, but that these powers also increasingly try to promote them as the basic principles for structuring international relations and regimes on a global level.
\end{abstract}

\section{Introduction}

In March 2013, during the fifth BRICS summit meeting in Durban, South Africa, the leaders of Brazil, Russia, India, China and South Africa (BRICS) launched the "eThekwini Action Plan', suggesting a further intensification and institutionalization of their co-operation in the field of foreign policy, including within the framework of the United Nations (BRICS, 2013). This action plan is the latest step in a development that started in 2001, when Jim O'Neill - chief economist of Goldman Sachs - coined the acronym 'BRIC' in order to focus on the enormous potential of the economies of four emerging (or re-emerging) powers: Brazil, Russia, India and China (O'Neill, 2001). Five years later, these four countries started a process of political dialogue when their ministers of foreign affairs met for the first time in the BRIC format in the margins of the 61st United Nations General Assembly in New York. From mid-2008 onwards, co-operation in the BRIC format was further strengthened by meetings of other ministers, including the ministers of finance, agriculture and health policy. The leaders of the four powers started meeting on

\footnotetext{
* Research for this article was conducted by Stephan Keukeleire in the framework of the Jean Monnet Chair in EU Foreign Policy at the Leuven International and European Studies (LINES) Institute of the University of Leuven (KU Leuven, Belgium) and of the Total Chair of EU Foreign Policy at the EU International Relations and Diplomacy Studies Department at the College of Europe (Bruges, Belgium). Bas Hooijmaaijers is a Research Fellow at the School of International and Public Affairs, Shanghai Jiao Tong University (China) and a Free Research Associate at LINES (KU Leuven, Belgium). The authors are grateful for the comments made by the anonymous reviewers and by the European and Asian scholars with whom they discussed the various drafts of this article. For up-to-date sources on EU-BRICS relations, see www.eufp.eu.
} 
a regular basis with the first annual BRIC summit meeting being held in 2009. Another BRIC breakthrough was made in December 2010 when Brazil, Russia, India and China decided to grant South Africa access to their group. In early 2011, 'BRIC' was transformed into 'BRICS', which increased the representativeness of the BRICS format, as it now also includes an African emerging power.

Despite the growing importance of the BRICS, the European Union (EU) has no genuine 'BRICS policy'. Neither has it formulated a policy to respond to the rise and growing influence and assertiveness of an increasing number of emerging powers and 'emerging power alliances' (Bava, 2011). Until recently, the BRICS countries as a group were rarely referred to in EU documents. This changed somewhat as in late 2011 and early 2012 the European Parliament (EP) discussed this theme, leading to a report on the EU's foreign policy towards the BRICS and other emerging powers (European Parliament, 2012). The EU still prefers an individual approach towards these countries, including through the development of bilateral 'strategic partnerships'. This preference also became clear, for example, in the intervention of Catherine Ashton - High Representative for Foreign Affairs and Security Policy and Vice-President of the European Commission (HR/VP) - in the debate in the EP on the EU's policy towards the BRICS and other emerging powers (Ashton, 2012). There are some good reasons for the EU's preference for bilateral relations with the BRICS countries. The BRICS format is indeed characterized by several limitations, despite its considerable economic and political potential.

This article argues that the BRICS co-operation must be seen within the wider context of various other emerging power alliances, such as BASIC (Brazil, South Africa, India, China) and IBSA (India, Brazil and South Africa) as well as other multilateral frameworks in the Asia-Pacific region and the global south in general. Taken together, these emerging power alliances and multilateral frameworks are increasingly influential. They present serious challenges for Europe in particular, in view of their defiance of the international order (in which Europe occupies privileged positions) and their different approaches towards multilateralism.

In recent academic literature attention has been focused on EU-Asia relations (Chaban and Holland, 2013; Christiansen et al., 2013; Hwee and Turner, 2012), EU-China relations (Holslag, 2011; Men and Balducci, 2010; Wouters et al., 2012b) and comparative regionalism in general (Doidge, 2011; Ikenberry et al., 2012; Murray, 2010). This article aims to fill a gap in the literature by assessing the BRICS and other emerging power alliances within the broader context of other multilateral settings in the Asia-Pacific region and the global south. By covering the various interrelated multilateral frameworks and emerging power alliances, the article strengthens our understanding of the potential challenges for the EU and its view on multilateralism.

Theoretically, the emerging power alliances and multilateral frameworks in the AsiaPacific region will be explained by pointing to the 'relations-oriented' perspective on multilateralism, which is included in the seminal article on multilateralism by Caporaso (1992). This perspective has to complement the more 'rules-oriented' perspective that is generally emphasized in the academic literature on multilateralism and also appears in the definition of 'multilateralism' provided by Ruggie (1992a, b).

The article consists of five parts. The first provides an overview of the differences and similarities between Brazil, Russia, India, China and South Africa. The second highlights the gradually increasing influence of the BRICS countries, using the example of the 
European financial and sovereign debt crisis. After that, the increasing influence of the BRICS as a group is situated within the wider context of emerging power alliances and other multilateral frameworks in the Asia-Pacific region and the global south. Making use of the conceptualizations of 'multilateralism' provided by Ruggie and Caporaso, the ensuing section analyzes these different views on multilateralism and points to the challenges for the EU and its perspective on multilateralism. The final section demonstrates how the EU failed to use the 'strategic partnerships' with the emerging powers to promote its view on multilateralism.

\section{The BRICS beyond Differences: Aiming to Reform the International Institutions}

Notwithstanding the intensification of their co-operation, the BRICS differ substantially in terms of demographic, economic, military and political weight (see Table 1) as well as in terms of their political and economic systems and their regional and global ambitions (Keukeleire et al., 2011; Renard and Biscop, 2012). The divergent and sometimes conflicting interests, as well as the territorial conflicts between China and India and between China and Russia, call into question the potential of the BRICS dialogue and co-operation to lead to a firm and coherent bloc.

Despite the differences, the BRICS countries also share some characteristics that distinguish them from other (emerging) powers and bring them closer to each other (Hurrell, 2006, pp. 1-3). First, they possess 'a range of economic, military and political power resources; some capacity to contribute to the production of international order, regionally or globally; and some degree of internal cohesion and capacity of state action' (Hurrell, 2006, p. 1). Second, they share the belief that they are entitled to a more influential role in world affairs. Third, they all lie outside or on the margin of the American-led set of international and multilateral structures and are not closely integrated in an alliance system with the United States. It is this combination of factors that leads to the willingness of the BRICS countries to strengthen their mutual relations and to promote

Table 1: The BRICS Countries: Statistical Overview

\begin{tabular}{|c|c|c|c|c|c|}
\hline & Brazil & China & India & Russia & $\begin{array}{l}\text { South } \\
\text { Africa }\end{array}$ \\
\hline Population in millions (2010) & 195.2 & $1,359.8$ & $1,205.6$ & 143.6 & 51.5 \\
\hline Surface area (in $1000 \mathrm{sq} \mathrm{km}$ ) & 8,514 & 9,600 & 3,287 & 17,098 & 1,219 \\
\hline GDP in billions of current US\$ (2012) & $2,252.7$ & $8,358.4$ & $1,841.7$ & $2,014.8$ & 384.3 \\
\hline GDP/capita in current US\$ (2012) & 11,340 & 6,188 & 1,489 & 14,037 & 7,508 \\
\hline EU-27 import (goods) in millions of euros (2012) & 37,254 & 289,902 & 37,328 & 212,882 & 20,525 \\
\hline EU-27 export (goods) in millions of euros (2012) & 39,630 & 143,833 & 38,467 & 123,016 & 25,526 \\
\hline Permanent member UN Security Council & No & Yes & No & Yes & No \\
\hline Nuclear weapons & No & Yes & Yes & Yes & No \\
\hline Defence expenditure in millions of current US\$ (2011) & 36,822 & 90,221 & 36,115 & 51,549 & 5,291 \\
\hline Defence expenditure as percentage of GDP (2011) & 1.48 & 1.24 & 1.98 & 2.79 & 1.29 \\
\hline Active military personnel (2012) & 318,500 & $2,285,000$ & $1,325,000$ & 845,000 & 62,100 \\
\hline
\end{tabular}

Sources: European Commission - DG Trade (2013); UN Department of Economic and Social Affairs, Population Division (2013); International Institute for Strategic Studies (2013); World Bank (2013a, 2013b). 
alternative or complementary international forums and linkages beyond the predominant western-dominated organizations.

Theoretically, both neo-realist assumptions and globalization theories point to the logic of the rise of the BRICS and of their intensified co-operation. On the one hand, the current international distribution of power fosters common balancing behaviour against the United States in an international context in which it still is the predominant power and in which none of the BRICS countries individually is yet strong enough to counterbalance it. On the other hand, 'globalization and ever denser networks of transnational exchange and communication create increasing demand for international institutions and new forms of governance' (Hurrell, 2006, p. 8).

Both theoretical perspectives help to explain why the BRICS countries continuously express their joint support for reforming the United Nations and the international financial institutions (IFIs) and for upgrading the role of the G20 (instead of the G7/8) as all the individual BRICS countries hold membership in the G20. This aim to reform the international institutions also appeared in the eThekwini Declaration, adopted by the leaders of the five BRICS countries during their fifth summit in 2013. In this declaration, they reiterate their support for a "comprehensive reform of the UN, including its Security Council, with a view to making it more representative, effective and efficient so that it can be more responsive to global challenges' (BRICS, 2013). The paragraph in the eThekwini Declaration on IFIs equally raises the issue of representation, as the BRICS leaders call for 'the reform of International Financial Institutions to make them more representative and to reflect the growing weight of BRICS and other developing countries' (BRICS, 2013).

These calls for reform reflect the willingness of the BRICS countries to counter an 'unjust' western-dominated multilateral world in which they are generally underrepresented (except for China and Russia in the UN Security Council). India, Brazil and South Africa do not have the status of permanent member of the UN Security Council, in contrast to the United Kingdom and France. The G7 only consists of western countries (including four European countries and a representative of the EU), with Russia sometimes joining them in the G8 format. The dominance of the west and the overrepresentation of Europe also appear in other multilateral settings such as the International Monetary Fund (IMF) and the World Bank (in which European countries have privileged positions) and the World Trade Organization (WTO) (in which the EU is one of the major actors). Although the division of labour between the EU and its Member States is not always very clear in terms of formal status and representation in many multilateral organizations, it is clear that Europe is over-represented (see Gstöhl, 2009; Jørgensen and Laatikainen, 2013). Together with the United States, the European countries also determined to a large extent the rules of the game in these international organizations, which explains why the EU is in general pleased with the existing system of multilateral governance.

\section{The European Financial Crisis and the Increasing Influence of the BRICS}

Five years after the launch of the co-operation within the BRICS framework, the formal setting of the main global political forums and the UN in particular remains largely unchanged. However, the economic power of the emerging countries proved to be stronger 
than predicted, and they have achieved some initial success in translating their economic weight into political leverage (Keukeleire et al., 2011).

An important moment in the light of multilateralism came with the credit crunch of 2008, when the G20 - pushed forward by the BRICS - entered the global stage in response to the financial crisis (Cherry and Dobson, 2012; Gowan, 2012). The financial and sovereign debt crisis in Europe has also led to a fundamental shift in Europe's position. The eurozone crisis has been raised on the agenda of the IFIs, some European countries have become recipients, and the EU has become dependent on non-European countries to find solutions to its problems. Emerging powers and China in particular proved to be significant contributors to both the global economic recovery and the emergency measures to tackle the crises in Europe (see Chen, 2012; Della Posta and Talani, 2011; Wang, 2011).

The financial and sovereign debt crisis in Europe had provided the perfect context for the emerging powers (and the United States) to get decisions agreed upon during the subsequent G20 meetings to tackle the over-representation of European states in the international financial institutions (Wade, 2011; Allen and Smith, 2012). Although visions on the significance of the G20 differ (Cammack, 2012; Cooper, 2010; Goodliffe and Sberro, 2012), the emerging powers have had some success in promoting their agenda. It was accepted in 2010 that the IMF voting system was to be reformed and that the share of emerging and developing countries should increase from 39.4 to 44.7 per cent, with the voting share of the developed countries decreasing by the same percentage (IMF, 2012). The reforms of the World Bank system of voting have led to a share of 47.19 per cent for the developing countries (World Bank, 2010). The aim of the developing countries was a share of 50 per cent in both the IMF and World Bank, which they have not yet achieved.

The role of the BRICS in tackling the European financial crisis was illustrated by their agreement in June 2012 to contribute to the IMF's US\$430 billion bail-out fund for the southern European countries, as they shared the opinion that the eurozone crisis threatened global economic and financial stability. The BRICS' total contribution amounted to US\$75 billion, with China's contribution being US\$43 billion, Brazil, India and Russia contributing US\$10 billion each and South Africa contributing US\$2 billion. The political significance of this contribution was stressed in the context of the informal meeting of the BRICS leaders ahead of the 2012 G20 summit in Mexico:

These new contributions are being made in anticipation that all the reforms agreed upon in 2010 will be fully implemented in a timely manner, including a comprehensive reform of voting power and reform of quota shares. (Ministry of External Affairs, India, 2012)

The BRICS countries thus connected the loans to long-delayed reforms that would give the emerging powers a stronger voice at the IMF by boosting their voting power as shareholders. Or as Emerson (2012, p. 1) observed: 'The conditionality tables are turned'.

One year later, the BRICS leaders went one step further than promoting reform of the existing Bretton Woods institutions. During their meeting in South Africa, they agreed to establish a 'New Development Bank' for mobilizing resources for projects in BRICS and other emerging economies and developing countries 'to supplement the existing efforts of multilateral and regional financial institutions' (BRICS, 2013). The agreement in principle conceals the fact that no consensus existed on fundamental issues, including the distribution of the projects, the headquarters of the bank and the financial means to be injected. 


\section{The Wider Picture: Other Emerging Power Alliances and Regional Organizations}

The common position and influence of the BRICS countries during the financial crisis is one example of how, despite their substantial differences, they can find common ground and have a significant impact on international developments. The importance of the BRICS framework and the challenges it poses for Europe can, however, only be properly understood if seen within the context of the growing number of increasingly influential 'emerging power alliances' (Bava, 2011) and other multilateral frameworks in the AsiaPacific region and the south in general. The BRICS format thus plays a significant role in, but is also only one component of, what Mahbubani (2008) described as the 'irresistible shift of global power to the east'. More generally, it is part of a rebalancing, of a trend where the centre of gravity is gradually and partially moving from the Euro-Atlantic to the Asia-Pacific area and from the north (or 'west') to the 'global south' (or 'east').

There are good reasons to warn against premature assumptions that the Asian century will arrive any time soon and that the EU will remain in a deep crisis. It is also important to emphasize the remaining interdependence between Asia and Europe, which implies that the fates and fortunes of the two regions cannot be that easily decoupled (Hwee, 2012). Nonetheless, the various emerging power alliances and other multilateral frameworks have one feature in common that is new for European states and EU foreign policy: they represent a world where the EU and Europe are largely absent and considered as far away (with the exceptions of the ASEAN Regional Forum and the Asia-Europe Meeting in which the Europeans participate). It is a world where the Europeans are also judged much less positively and as far less relevant than European self-perception might indicate (see Chaban and Holland, 2013; Fioramonti, 2012; Jain and Pandey, 2010; Lucarelli and Fioramonti, 2010).

The purpose of this section is to give an overview of the main (partially overlapping) emerging power alliances and other multilateral settings in the Asia-Pacific region that are centred around the BRICS countries (see Figure 1). In view of their varied membership and their varying trajectories, objectives, instruments and levels of legitimacy, these emerging power alliances and multilateral settings can come into competition with each other, but can also be mutually reinforcing and complementary. The large number of power alliances and multilateral settings, in combination with the limited length of this article, does not allow for a separate analysis of each of them. Furthermore, the forums included in this section are only a limited part of the more than 100 multilateral groupings in the region (Bouchard and Peterson, 2011, p. 26). However, the descriptive overview in this section will be followed by an analysis of their main common features (for a comprehensive analysis of Asian regionalism, see Stubbs and Beeson, 2012).

In addition to the BRICS, the shift in the international balance of power encompasses other power alliances that are variations on the BRICS setting, including the BASIC, IBSA and RIC formats. The BASIC format with Brazil, South Africa, India and China was launched in November 2009 with a Joint Strategy for the UN Framework Convention on Climate Change (UNFCCC) Conference in Copenhagen where the four countries eventually sidelined the EU and negotiated a deal with the United States. This was one of the first successes of the emerging powers in jointly translating their economic weight into political leverage (Hallding et al., 2011). Since 2009, ministerial meetings have taken 
Figure 1: Emerging Power Alliances and Other Multilateral Frameworks

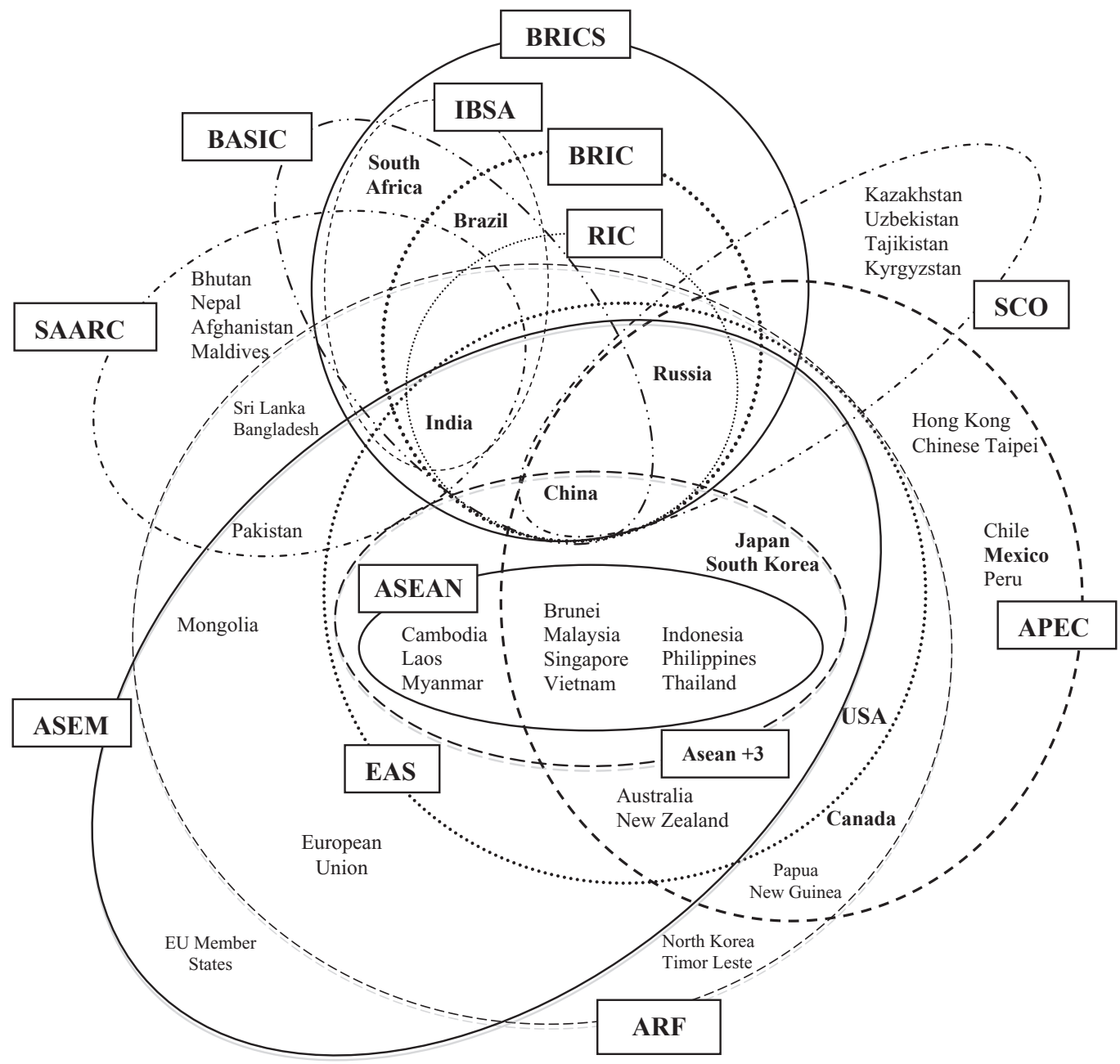

APEC: Asia-Pacific Economic Cooperation ARF: ASEAN Regional Forum

ASEAN: Association of South East Asian Nations

ASEAN+3: ASEAN + Japan, Korea, China

ASEM: Asia-Europe Meeting

BASIC: Brazil, South Africa, India, China

BRIC: Brazil, Russia, India, China

BRICS: Brazil, Russia, India, China, South Africa
EAS: East Asia Summit

IBSA: India, Brazil, South Africa

RIC: Russia, India, China

SAARC: South Asian Association for Regional

Cooperation

SCO: Shanghai Cooperation Organisation

Countries in bold are considered by the EU as 'strategic partners'

Source: Own design based on Keukeleire and Bruyninckx (2011, p. 400).

place quarterly on climate change and environmental issues. The trilateral IBSA Dialogue Forum comprising India, Brazil and South Africa was formally launched in 2003. The forum can be considered as coalition-building between southern countries, as well as a vehicle for change in international relations and trilateral co-operation in 16 sectors including development, energy security, health policies and infrastructure (Vieira 
and Alden, 2011; Flemes, 2009; Chenoy, 2010). RIC refers to trilateral dialogue between representatives of Russia, India and China. The first meeting between the foreign ministers of these countries in the RIC Trilateral Forum was held in the margins of the UN General Assembly in 2002. In April 2012 the 11th trilateral meeting of the foreign ministers of Russia, India and China was held. However, convening a RIC summit with the three leaders has not yet been attempted, suggesting a lack of progress in their co-operation.

Important, too, are the various networks that were established around ASEAN. The Association of Southeast Asian Nations (ASEAN) comprises Brunei Darussalam, Cambodia, Indonesia, Laos, Malaysia, Myanmar, Philippines, Singapore, Thailand and Vietnam. ASEAN's aims include acceleration of economic growth, social progress and cultural development as well as the promotion of regional peace and stability (Jetschke, 2012; Tang, 2012; Wunderlich, 2012). ASEAN can be considered the most advanced attempt at regional co-operation in Asia (Cameron, 2012). The ASEAN+3 co-operation was launched in 1997 and encompasses the ASEAN countries plus China, Japan and Korea. These countries focus on several sectors including political-security, financial and economic as well as socio-cultural co-operation. Important in this context are the initiatives of the ASEAN+3 finance ministers and the actions to design an east Asian financial architecture (Sohn, 2011; Terada, 2012).

The East Asia Summit (EAS) is a multilateral forum for dialogue on broad economic, political and strategic issues of common interest in east Asia and is concerned with promoting economic prosperity, peace and stability in this region (Camroux, 2012). The EAS includes China and India, together with several other Asian countries as well as Australia and New Zealand. From late 2011 onwards, the membership has been extended to 18 countries with the United States and Russia joining this forum.

Another player in the Asia-Pacific region is the Asia-Pacific Economic Co-operation (APEC). Within the APEC framework co-operation takes place between 21 states in the Asia-Pacific region, including major powers such as China, the United States and Russia and other emerging or mid-sized powers in Asia (including the ASEAN countries as well as Japan and Korea), the American continent (Canada, Mexico, Peru and Chile), plus Australia and New Zealand making it, unlike ASEAN, not an exclusively Asian institution (Bisley, 2012; Moon, 2011). Together, these countries account for approximately 40 per cent of the world's population, 44 per cent of world trade and 54 per cent of world gross domestic product (GDP). APEC covers a wide range of economy-related policy fields, including international environmental politics. The positions of the BASIC countries and the United States in the UNFCCC summit reflected those adopted in a preceding APEC summit and subsequently brought to the negotiations in Copenhagen (Keukeleire and Bruyninckx, 2011).

Potentially significant, too, is the Trans-Pacific Partnership (TPP) (not included in Figure 1). The TPP is a proposed free trade agreement under negotiation since 2010 by currently 12 countries, including Australia, Brunei, Canada, Chile, Japan, Malaysia, Mexico, New Zealand, Peru, Singapore, the United States and Vietnam. The aim is to produce a comprehensive agreement that could contribute toward taming the tangle of preferential trade agreements in the Asia-Pacific region and be a potential stepping stone to achieving the long-term APEC goal of liberalizing trade among its member economies (Capling and Ravenhill, 2011). 
Two other networks with a wider membership are SAARC and SCO. The South Asian Association for Regional Co-operation (SAARC) includes Afghanistan, Bangladesh, Bhutan, India, Maldives, Nepal, Pakistan and Sri Lanka. Nine countries, including China and the United States, as well as the EU, have observer status. SAARC is mainly focused on cultural, economic and technological development with co-operation in over a dozen areas. However, regional instability and a lack of trust among its members make SAARC a rather weak organization. In its over 25-year history it has been able to establish a South Asian Free Trade Area (SAFTA), but this is considered a rather poor track record, especially with direct trade between the two largest SAARC members - India and Pakistan - being relatively small (Saez, 2011). The Shanghai Co-operation Organization (SCO) was established in 2001. It includes Russia, China, Kazakhstan, Uzbekistan, Tajikistan and Kyrgyzstan, with India, Pakistan, Iran and Mongolia having observer status and Belarus and Sri Lanka being dialogue partners (Chung, 2012; Takagi, 2012). The presence of China and Russia poses a paradox for the organization. While both countries obviously overshadow the smaller SCO members, the organization would have troubles surviving without them (Naarajärvi, 2012). Although both SAARC and SCO present interesting potential for co-operation and stability in the region, this potential remains mainly theoretical given their poor performance records so far (Renard, 2013).

Only two of the co-operation frameworks include the EU or its Member States. The Asia-Europe Meeting (ASEM) was initiated in 1996. It is an informal process of dialogue and co-operation comprising the 28 EU Member States, the European Commission, 19 Asian countries and the ASEAN Secretariat. After more than 15 years in operation, ASEM has not been able to put its stamp on region-to-region relations. Instead of drawing on global institutions as the background or fundamental principles against which the AsiaEurope Meeting functions, it has instead duplicated to a substantial extent the agenda of these institutions (Gilson, 2012). The ASEAN Regional Forum (ARF) is a forum for multilateral dialogue aiming to foster dialogue and consultation, and promote confidencebuilding and preventive diplomacy in the Asia-Pacific region. At the moment, the ARF has 27 participants including the EU. The almost two-decade history of the ARF since its formation can be largely seen as a period of stagnation rather than of steady progress. This stagnation primarily derives from the lack of mutual trust among participating states and differing views about its desirable functions (Yuzawa, 2012).

The emerging power alliances and other multilateral frameworks mapped out in this section differ in terms of scope and reach as well as in terms of coherence and impact. However, they are all part of the gradual transformation of the global political landscape, with the BRICS being only 'one of the overlapping non-western formations to emerge in the new era of bloc-building' (Gowan, 2012, p. 167). Whereas none of them is in itself very influential, taken together, they are not at all inconsequential for the EU and its position on multilateralism.

\section{Different Perspectives on Multilateralism and Challenges for the EU}

Before looking at the various positions on multilateralism, it is useful to recall the most commonly used definition of the term as 'an institutional form which co-ordinates relations among three or more states on the basis of "generalized" principles of conduct - that 
is, principles which specify appropriate conduct for a class of action' (Ruggie, 1992a, p. 571). In the academic literature, these principles of conduct or rules are strongly emphasized, leading to the observation of Bouchard and Peterson (2011, p. 10) that 'the importance of rules' is one of the main dimensions stressed by all interpretations of multilateralism. They therefore define multilateralism as ' $[\mathrm{t}] \mathrm{hree}$ or more actors engaging in voluntary and (essentially) institutionalized international cooperation governed by norms and principles, with rules that apply (by and large) equally to all states' (Bouchard and Peterson, 2011, p. 10).

The EU's position on multilateralism mirrors strongly this emphasis on rules. The EU's 'effective multilateralism' doctrine is characterized by a preference for legally binding commitments and powerful international regimes as the outcomes and instruments of multilateral co-operation. For the EU, rules should not only cover economic relations and policies but also other policy fields (such as the environment or social policy) as well as the internal organization of Member States (including respect for human rights or rule of law). Importantly, for the EU these binding rules are not seen as an assault on national sovereignty (see Bouchard et al., 2013; Commission, 2003; Wouters et al., 2012a).

When assessing the various emerging power alliances and multilateral frameworks in the Asia-Pacific region, it appears that the Asian countries and emerging powers have made 'the choice for multilateralism' too - just like the Europeans - but it is a choice based on fundamentally different principles. In terms of substance, they prioritize economic growth and development, with a reluctance to let the economy be restricted by concerns that Europeans consider important, such as the environment, social protection or human rights. They have a clear preference for a purely intergovernmental approach: decision-making by consensus, absence of treaty obligations, voluntary commitments and respect for national sovereignty (see also Narine, 2012). This is reflected in the formal institutions of the Asian regional co-operation frameworks being much weaker than in Europe (Qin, 2011, p. 118).

Qin refers in this context to what he labels as 'relational governance', which he differentiates from 'rule-based governance'. Relational governance emphasizes the governance of relationships between actors; it is process-oriented, with the process being considered as a collection of ongoing complex relations (Qin, 2011, pp. 138-9). This difference between rules-orientation and relations-orientation is also relevant for conceptualizing the various perspectives on multilateralism.

The focus on a 'rules-oriented' perspective on multilateralism in the academic literature tends to push into the background the more 'relations-oriented' perspective that was emphasized in another seminal article on multilateralism. Caporaso (1992), in his analysis of theoretical routes to understanding multilateral activities, explores socialcommunicative and institutional approaches that emphasize debate, communication, deliberation, persuasion, argumentation and discursive legitimation within the multilateral activity. The multilateral setting is then to be seen as a 'forum' where agents reflect, discuss, trust and distrust, justify as well as signal moves, alter the other's perceptions of the world, and try to build consensus. Identifying and solving problems are possible in this context, but are not at the heart of the multilateral activity (Caporaso, 1992, pp. 613-14). Multilateral institutions offer an environment in which socialization and learning can occur, in which continuous contacts and exchange of information serve to alter 
perceptions about both interests and the means to achieve them, and in which trust can be increased and uncertainty about actions of others reduced (Caporaso, 1992, pp. 625-27).

Looking at the agendas and outcomes of the various emerging power alliances and multilateral frameworks in the Asia-Pacific region, it appears that, together, they constitute an increasingly dense set of partially overlapping formal and informal networks on all political, diplomatic and administrative levels. They cover an ever wider scope of policy areas, and provide opportunities for debate, communication and deliberation - all reflecting the features of relations-oriented multilateralism. Europeans often dismiss these various forums for dialogue and co-operation as insignificant, especially in view of their limited institutionalization, the lack of binding commitments and the often substantial divergences among participating countries. However, taken together, they are not inconsequential.

First, whereas the EU had hoped at the start of the millennium that its model of 'effective multilateralism' would gradually become the global standard, with the EU becoming a core actor within this multilateral system, one decade later the EU sees the limits of its approach, as well as the limited support for of its view on multilateralism. On the contrary, the more relations-oriented forms of multilateralism in the Asia-Pacific region and emerging powers constellations point to the increasing attraction of alternative forms of multilateralism. This provides an additional argument to support the caution formulated by Bouchard and Peterson (2011, p. 11; see also Caporaso, 1992, p. 604) with regards to overly optimistic claims that 'today's multilateralism is more binding, rulesbased, and demanding than past versions'.

Second, in view of the lack of trust between various Asian countries and the danger of escalation of conflicts (see Bisley, 2012; Endo, 2012; He and Inoguchi, 2011; Yuzawa, 2012), the opportunities provided to political leaders and diplomats of these countries to meet each other on an increasingly frequent basis can as such have a positive impact. The various forums allow them to discuss and try to tackle the various conflicts of interests and try to avoid an escalation of conflicts. Such an escalation would have detrimental effects on the international stability and international economy at large, and could thus also have an impact on Europe.

Third, the various emerging power alliances and multilateral frameworks in the AsiaPacific region are not only important to manage mutual relations in the region. They increasingly inform and impact upon national policies. Even if the deliberations within groupings such as the BRICS, BASIC or APEC do not lead to binding rules, they can affect national policies if countries within their national policy-making processes take into account the deliberations within these settings - for instance, when these contribute to changing perceptions about interests and the means to achieve them (see Caporaso, 1992, p. 625).

Fourth, as indicated above, these deliberations can have an impact on the position adopted by these countries in international negotiation processes where the EU is confronted with these 'competing multilateralisms'. This means that, even if these deliberations do not lead to the adoption of rules, they can be used to co-ordinate positions regarding the changing of rules in international organizations in which Europeans are over-represented (such as the IMF and World Bank) or to oppose the binding commitments proposed by the EU (such as in the UNFCCC Conference in Copenhagen). 
The difference in views on multilateralism between the EU and the emerging countries is not a black-and-white issue, however. For example, a shift towards more ruleoriented multilateralism could be observed at the Durban UNFCCC Conference in 2011 where three of the four BASIC countries - Brazil, South Africa and China - softened their initial negative stance vis-à-vis legally binding commitments (Banerjee, 2012, p. 1780; see also below).

\section{The EU's 'Strategic Partnerships' and Multilateralism}

The EU has not yet developed an effective policy to deal with the generally changing balance of power in the 21st century. This is linked to the EU's struggle to focus not only on the main Asian power, China, but to also find a way for 'anchoring AsiaEurope relations' in general (Hwee and Turner, 2012). To deal with the rise of emerging powers, the EU has launched bilateral 'strategic partnerships' with ten third countries, including the five BRICS countries (Grevi and Khandekar, 2011; Keukeleire and Delreux, 2014, pp. 290-4; Renard, 2011; Renard and Biscop, 2012). These so-called 'strategic partnerships' are defined by the EU as building blocks of an effective multilateral order with the UN at its apex (European Council, 2008).

In general, the formal relations with these five emerging countries follow the same pattern, although it may be more correct to speak about 'differentiated strategic partnerships' (see overview in Sautenet, 2012). The legal bases for these partnerships are long-term partnership and co-operation agreements, or co-operation agreements. These agreements are mostly trade-related, but also touch upon policies that go beyond trade, such as energy, global warming and foreign and security policy. Furthermore, annual summits (in the case of Russia: biannual summits), ministerial meetings as well as sectoral dialogues between EU officials and representatives of these third countries take place on a regular basis, contributing to the establishment of institutional frameworks. However, the strategic partnerships of the EU with Brazil, China, India, Russia and South Africa have not helped to overcome the different views and interests of the EU and the emerging powers (Renard and Biscop, 2012). Although labelled as "partnerships for effective multilateralism' (Grevi and De Vasconcelos, 2008), the EU has only to a limited extent succeeded in using the regular dialogue and summit meetings with the various powers to convince them of the EU's views on effective multilateralism in general and about the EU's position in specific multilateral negotiations.

The example of the 2009 Copenhagen Conference on climate change was illuminating in this respect. The EU had met several of its 'strategic partners' in the months preceding the Conference, which had important issues on the agenda. The joint declarations issued after these meetings gave the impression that the EU and its partners could find some common ground, despite the diverging approaches. But finally, during the Copenhagen Conference, the 'strategic partners' completely sidelined the EU and its position on how to shape the future climate change regime (Hurrell and Sengupta, 2012; Keukeleire and Bruyninckx, 2011; van Schaik and Schunz, 2012). The EU drew lessons from the experience in Copenhagen and recognized that it can only promote its ambitious objectives if it also takes into account the views of its strategic partners. At the 2011 Durban Conference, the EU moderated its ambitions, found a new role for itself as a bridge builder, and saw Brazil, China and South Africa moving in its 
direction. The Durban meeting also showed cracks appearing in the BASIC group, indicating that the coherence of the emerging powers should not be overemphasized (Banerjee, 2012; Groen et al., 2012).

Nonetheless, the surprise of the Europeans about their isolated position during the Copenhagen Conference pointed to a major flaw in the EU's approach towards the emerging powers and the 'strategic partnerships'. The Europeans have to listen genuinely, to fully understand and appreciate the positions, principles and interests of the partners, and to take them seriously in the subsequent multilateral and bilateral negotiations. The EU and its Member States are starting to learn that the diffusion of international norms has become a two-way process $(\mathrm{Pu}, 2012)$ and that Europe will have to be more ready to accept 'difference' instead of seeing the European model and preferences as generalizable to the rest of the world (see Acharya and Buzan, 2010; Chakrabarty, 2007; Inayatullah and Blaney, 2004; Tickner and Blaney, 2012). This is necessary in view of a new 21st-century order that accommodates the emerging powers and is sensitive to the needs of the global south (Howorth, 2010). The challenge for future generations of Europeans, including European scholars, is not merely to better know and understand Asia (Wang, 2012), but also the various forms of multilateralism in the Asia-Pacific region and the global south.

\section{Conclusions}

This article has analyzed the BRICS and other emerging power alliances and multilateral frameworks in the Asia-Pacific as well as the challenges they pose for the EU and for its view on multilateralism. The differences between the emerging powers raise doubts about the likelihood of the BRICS framework being transformed into a firm and coherent bloc. However, what unites these countries is the willingness to transform the predominantly western-dominated international organizations, inherited from a 20thcentury context, in which Europe is over-represented (in the UN Security Council, G7/8, IMF and World Bank). The rise and potential of the BRICS needs to be situated in the context of other partially overlapping emerging powers alliances as well as multilateral organizations in the Asia-Pacific region. Together, they contribute to and are part of a global power shift from the Euro-Atlantic to the Asia-Pacific area and from the north to the east and 'global south'.

None of the variations on Asian regionalism and emerging powers alliances is in itself very influential. However, taken together, they have an impact on the EU and the European view on multilateralism, particularly as their choice for multilateralism differs from the EU's choice in terms of content (with a prioritization of economic development) and methodology (with an emphasis on national sovereignty and a reluctance to accept binding commitments). Referring to the conceptualizations provided by Ruggie, Caporaso and Qin, a differentiation can also be made between a 'rules-oriented multilateralism' promoted by the EU (prioritizing the creation of binding rules to pursue policy goals) and a 'relations-oriented multilateralism' which focuses on relations and interactions between the actors as the core of the multilateral activities in the AsiaPacific region.

To deal with the rise of emerging powers the EU has launched various 'strategic partnerships' with these countries. However, the EU has not been able to use these 
partnerships to promote its view on effective multilateralism. More generally, the EU has not yet developed a policy to deal with the generally changing balance of power in the $21 \mathrm{st}$ century - a phenomenon in which the emergence of the BRICS and other power alliances and multilateral networks needs to be situated.

Correspondence:

Stephan Keukeleire

Leuven International and European Studies (LINES)

University of Leuven (KU Leuven)

Parkstraat 45, Bus 3602

B-3000 Leuven

Belgium

email: stephan.keukeleire@soc.kuleuven.be

\section{References}

Acharya, A. and Buzan, B. (2010) Non-Western International Relations Theory: Perspectives on and beyond Asia (London: Routledge).

Allen, D. and Smith, M. (2012) 'Relations with the Rest of the World'. JCMS, Vol. 50, No. 1, pp. $162-77$.

Ashton, C. (2012) 'Speech on EU Foreign Policy towards the BRICS and Other Emerging Powers', 1 February. Speech 12/56. Available at: «http://europa.eu/rapid/pressReleases».

Banerjee, S.B. (2012) 'A Climate for Change? Critical Reflections on the Durban United Nations Climate Change Conference'. Organization Studies, Vol. 33, No. 12, pp. 1761-86.

Bava, U.S. (2011) 'Emerging Power Alliances in Perspective: IBSA, BRIC, BASIC'. In Kornegay, F. and Masters, L. (eds) From BRIC to BRICS (Pretoria: Institute for Global Dialogue).

Bisley, N. (2012) ‘APEC: Asia-Pacific Economic Cooperation'. In Stubbs, R. and Beeson, M. (eds).

Bouchard, C. and Peterson, J. (2011) 'Conceptualising Multilateralism: Can We All Just Get Along?' Mercury E-paper, Vol. 1. Available at: «http://mercury.uni-koeln.de/fileadmin/ user_upload/E-paper_no1_r2010.pdf».

Bouchard, C., Peterson, J. and Tocci, N. (eds) (2013) The European Union and Multilateralism in the 21st Century (Abingdon: Routledge).

BRICS (2013) 'eThekwini Declaration: Fifth BRICS Summit', 27 March. Available at: «http:// www.mea.gov.in/bilateral-documents».

Cameron, F. (2012) 'The European Integration Model: What Relevance for Asia?' In Ikenberry, J.G., Yamamoto, Y. and Haba, K. (eds) Regional Integration and Institutionalization: Comparing Asia and Europe (Kyoto: Shoukadoh).

Cammack, P. (2012) 'The G20, the Crisis and the Rise of Global Developmental Liberalism'. Third World Quarterly, Vol. 33, No. 1, pp. 1-16.

Camroux, D. (2012) 'The East Asia Summit: Pan-Asian Multilateralism Rather than Intra-Asian Regionalism'. In Stubbs, R. and Beeson, M. (eds).

Capling, A. and Ravenhill, J. (2011) 'Multilateralising Regionalism: What Role for the TransPacific Partnership Agreement?' Pacific Review, Vol. 24, No. 5, pp. 553-75.

Caporaso, J.A. (1992) 'International Relations Theory and Multilateralism: The Search for Foundations'. International Organization, Vol. 46, No. 3, pp. 599-632.

Chaban, N. and Holland, M. (eds) (2013) Europe and Asia: Perceptions from Afar (Baden-Baden: Nomos).

Chakrabarty, D. (2007) Provincializing Europe: Postcolonial Thought and Historical Difference (Princeton, NJ: Princeton University Press). 
Chen, Z. (2012) 'Europe as a Global Player: A View from China'. Perspectives, Vol. 20, No. 2, pp. 7-30.

Chenoy, K.M. (2010) 'IBSA, Plurilateralism and the Global South'. In Andrade, M., Soares, F.V. and Lal, R. (eds) What can IBSA Offer to the Global Community? (Brasilia: International Policy Centre for Inclusive Growth).

Cherry, J. and Dobson, H. (2012) “"Seoul-Searching”: The 2010 G-20 Seoul Summit'. Global Governance, Vol. 18, No. 3, pp. 363-81.

Christiansen, T., Kirchner, E. and Murray, P. (eds) (2013) The Palgrave Handbook of EU-Asia Relations (Basingstoke: Palgrave Macmillan).

Chung, C.-P. (2012) 'Phases in the Development of the Shanghai Cooperation Organization'. In Beeson, M. and Stubbs, R. (eds).

Commission of the European Communities (2003) 'The European Union and the United Nations: choice of multilateralism'. $\operatorname{COM(2003)} 526$.

Cooper, A.F. (2010) 'The G20 as an Improvised Crisis Committee and/or a Contested "Steering Committee" for the World'. International Affairs, Vol. 86, No. 3, pp. 741-57.

Della Posta, P. and Talani, L.S. (eds) (2011) Europe and the Financial Crisis (Basingstoke: Palgrave Macmillan).

Doidge, M. (2011) The European Union and Interregionalism: Patterns of Engagement (Farnham: Ashgate).

Emerson, M. (2012) 'Implications of the Eurozone Crisis for EU Foreign Policy: Costs and Opportunities'. CEPS Commentary, June.

Endo, K. (2012) 'Is Comparative Regionalism Possible? The Security-Economy-Normative Nexus in Europe and East Asia'. In Ikenberry, J.G., Yamamoto, Y. and Haba, K. (eds) Regional Integration and Institutionalization: Comparing Asia and Europe (Kyoto: Shoukadohs).

European Commission - DG Trade (2013) Website. Available at: «http://ec.europa.eu/trade/».

European Council (2008) Report on the Implementation of the European Security Strategy: Providing Security in a Changing World (Brussels: European Union).

European Parliament (2012) Report on the EU Foreign Policy towards the BRICS and Other Emerging Powers: Objectives and Strategies. Available at: «http://www.europarl.europa.eu/».

Fioramonti, L. (2012) 'Is the EU a "Better" Global Player? An Analysis of Emerging Powers' Perceptions'. In Renard, T. and Biscop, S. (eds).

Flemes, D. (2009) 'India-Brazil-South Africa in the New Global Order: Interests, Strategies and Values of the Emerging Coalition'. International Studies, Vol. 46, No. 4, pp. 401-21.

Gilson, J. (2012) 'The Asia-Europe Meeting (ASEM)'. In Stubbs, R. and Beeson, M. (eds).

Goodliffe, G. and Sberro, S. (2012) 'The G20 after Los Cabos: Illusions of Global Economic Governance'. International Spectator, Vol. 47, No. 4, pp. 1-16.

Gowan, R. (2012) 'Asymmetrical Multilateralism: The BRICS, the US, Europe and the Reform of Global Governance (2005-2011)'. In Renard, T. and Biscop, S. (eds).

Grevi, G. and De Vasconcelos, A. (eds) (2008) Partnerships for Effective Multilateralism: EU Relations with Brazil, China, India and Russia (Paris: Institute for Security Studies).

Grevi, G. and Khandekar, G. (2011) Mapping EU Strategic Partnerships (Madrid: FRIDE).

Groen, L., Niemann, A. and Oberthür, S. (2012) 'The EU as a Global Leader? The Copenhagen and Cancun UN Climate Change Negotiations'. Journal of Contemporary European Research, Vol. 8, No. 2, pp. 173-91.

Gstöhl, S. (2009) "“Patchwork Power" Europe: The EU's Representation in International Institutions'. European Foreign Affairs Review, Vol. 14, No. 3, pp. 385-403.

Hallding, K., Olsson, M., Atteridge, A., Vihma, A., Carson, M. and Roman, M. (2011) Together Alone: BASIC Countries and the Climate Change Conundrum (Copenhagen: Norden - Nordic Council of Ministers). 
He, B. and Inoguchi, T. (2011) 'Introduction to Ideas of Asian Regionalism'. Japanese Journal of Political Science, Vol. 12, No. 2, pp. 165-77.

Holslag, J. (2011) 'The Elusive Axis: Assessing the EU-China Strategic Partnership'. JCMS, Vol. 49, No. 2, pp. 293-313.

Howorth, J. (2010) 'The EU as a Global Actor: Grand Strategy for a Global Grand Bargain?' JCMS, Vol. 48, No. 3, pp. 455-74.

Hurrell, A. (2006) 'Hegemony, Liberalism and Global Order: What Space for Would-Be Great Powers?' International Affairs, Vol. 82, No. 1, pp. 1-19.

Hurrell, A. and Sengupta, S. (2012) 'Emerging Powers, North-South Relations and Global Climate Politics'. International Affairs, Vol. 88, No. 3, pp. 463-84.

Hwee, Y.L. (2012) 'Introduction'. In Hwee, Y.L. and Turner, B. (eds).

Hwee, Y.L. and Turner, B. (eds) (2012) Changing Tides and Changing Ties: Anchoring AsiaEurope Relations (Singapore: EU Centre in Singapore).

Ikenberry, J.G., Yamamoto, Y. and Haba, K. (eds) (2012) Regional Integration and Institutionalization: Comparing Asia and Europe (Kyoto: Shoukadoh).

Inayatullah, N. and Blaney, D.L. (2004) International Relations and the Problem of Difference (New York: Routledge).

International Institute for Strategic Studies (IISS) (2013) The Military Balance 2013: Annual Assessment of the Military Capabilities and Defence Economics (London: IISS).

International Monetary Fund (IMF) (2012) 'Quotas Factsheet'. Available at: «http://www.imf.org/ external/np/exr/facts/quotas.htm».

Jain, R.K. and Pandey S. (2010) 'The European Union in the Eyes of India'. Asia Europe Journal, Vol. 8, No. 2, pp. 193-209.

Jetschke, A. (2012) 'ASEAN'. In Stubbs, R. and Beeson, M. (eds).

Jørgensen, K.E. and Laatikainen, K.V. (eds) (2013) Routledge Handbook on the European Union and International Institutions: Performance, Policy, Power (London: Routledge).

Keukeleire, S. and Bruyninckx, H. (2011) 'The European Union, the BRICs and the Emerging New World Order'. In Hill, C. and Smith, M. (eds) International Relations and the European Union (2nd edition) (Oxford: Oxford University Press).

Keukeleire, S. and Delreux, T. (2014) The Foreign Policy of the European Union (2nd edition) (Basingstoke: Palgrave Macmillan).

Keukeleire, S., Mattlin, M., Hooijmaaijers, B., Behr, T., Jokela, J., Wigell, M. and Kononenko, V. (2011) The EU Foreign Policy towards the BRICS and Other Emerging Powers: Objectives and Strategies (Brussels: European Parliament DG External Policies).

Lucarelli, S. and Fioramonti, L. (eds) (2010) External Perceptions of the European Union as a Global Actor (Abingdon: Routledge).

Mahbubani, K. (2008) The New Asian Hemisphere: The Irresistible Shift of Global Power to the East (New York: Public Affairs).

Men, J. and Balducci, G. (eds) (2010) Prospects and Challenges for EU-China Relations in the 21st Century: The Partnership and Cooperation Agreement (Brussels: P.I.E. Peter Lang).

Ministry of External Affairs, India (2012) 'Media Note on the Informal Meeting of the BRICS Leaders Ahead of the G20 Summit in Los Cabos'. Available at: «http://www.mea.gov.in/in -focus-article.htm».

Moon, W. (2011) 'Whither East Asian Economic Integration? Korea's Regionalization cum Globalization Strategy'. Asia Europe Journal, Vol. 9, No. 1, pp. 29-42.

Murray, P. (2010) 'East Asian Regionalism and EU Studies'. Journal of European Integration, Vol. 32, No. 6, pp. 597-616.

Naarajärvi, T. (2012) 'China, Russia and the Shanghai Cooperation Organisation: Blessing or Curse for New Regionalism in Central Asia?’ Asia Europe Journal, Vol. 10, No. 2-3, pp. 113-26. 
Narine, S. (2012) 'Asia, ASEAN and the Question of Sovereignty: The Persistence of Nonintervention in the Asia-Pacific'. In Stubbs, R. and Beeson, M. (eds).

O’Neill, J. (2001) 'Building Better Global Economic BRICs'. Global Economics Papers, Vol. 66, pp. $1-16$.

Pu, X. (2012) 'Socialisation as a Two-Way Process: Emerging Powers and the Diffusion of International Norms'. Chinese Journal of International Politics, Vol. 5, No. 4, pp. 34167.

Qin, Y. (2011) 'Rule, Rules and Relations: Towards a Synthetic Approach to Governance'. Chinese Journal of International Politics, Vol. 4, No. 2, pp. 117-45.

Renard, T. (2011) 'The Treachery of Strategies: A Call for True EU Strategic Partnerships'. Egmont Papers, Vol. 45.

Renard, T. (2013) 'The EU, the SCO and SAARC'. In Christiansen, T., Kirchner, E. and Murray, P. (eds) The Palgrave Handbook of EU-Asia Relations (Basingstoke: Palgrave Macmillan).

Renard, T. and Biscop, S. (eds) (2012) The EU and Emerging Powers in the 21st Century: How Europe Can Shape a New Global Order (Farnham: Ashgate).

Ruggie, J.G. (1992a) 'Multilateralism: The Anatomy of an Institution'. International Organization, Vol. 46, No. 3, pp. 561-98.

Ruggie, J.G. (ed.) (1992b) Multilateralism Matters: The Theory and Praxis of an Institutional Form (New York: Columbia University Press).

Saez, L. (2011) The South Asian Association for Regional Cooperation (SAARC): An Emerging Collaboration Architecture (Abingdon: Routledge).

Sautenet, A. (2012) 'The EU's Strategic Partnerships with Emerging Powers: Institutional, Legal, Economic and Political Perspectives'. In Renard, T. and Biscop, S. (eds).

Sohn, I. (2011) 'After Renaissance: China's Multilateral Offensive in the Developing World'. European Journal of International Relations, Vol. 18, No. 1, pp. 77-101.

Stubbs, R. and Beeson, M. (eds) (2012) Routledge Handbook of Asian Regionalism (London: Routledge).

Takagi, S. (2012) 'China and the Shanghai Cooperation Organization, 1996-2007'. In Ikenberry, J.G., Yamamoto, Y. and Haba, K. (eds).

Tang, C.-M. (2012) 'Southeast Asian Peace Revisited: A Capitalist Trajectory'. International Relations of the Asia-Pacific, Vol. 12, No. 3, pp. 389-417.

Terada, T. (2012) ‘ASEAN Plus Three: Becoming More Like a Normal Regionalism?' In Stubbs, R. and Beeson, M. (eds).

Tickner, A.B. and Blaney, D.L. (eds) (2012) Thinking International Relations Differently (Abingdon: Routledge).

United Nations Department of Economic and Social Affairs, Population Division (2013). Website. Available at: «http://www.un.org/esa/population/unpop.htm».

van Schaik, L. and Schunz, S. (2012) 'Explaining EU Activism and Impact in Global Climate Politics: Is the Union a Norm- or Interest-Driven Actor?' JCMS, Vol. 50, No. 1, pp. 16986.

Vieira, M.A. and Alden, C. (2011) 'India, Brazil and South Africa (IBSA): South-South Cooperation and the Paradox of Regional Leadership'. Global Governance, Vol. 17, pp. 507-28.

Wade, R.H. (2011) 'Emerging World Order? From Multipolarity to Multilateralism in the G20, the World Bank and the IMF'. Politics and Society, Vol. 39, No. 3, pp. 347-78.

Wang, G. (2012) 'The China Effect in Anxious Europe'. Asia Europe Journal, Vol. 10, pp. 12945.

Wang, X. (2011) 'Understanding China's Role in the Post-Financial Crisis World'. In Secchi, C. and Villafranca, A. (eds) Global Governance and the Role of the EU: Assessing the Future Balance of Power (Cheltenham: Edward Elgar). 
World Bank (2010) 'World Bank Reforms Voting Power, Gets \$86 Billion Boost'. Press Release 2010/363/EXT. Available at: «http://web.worldbank.org».

World Bank (2013a) 'World Development Indicators 2013'. Available at: «http://databank .worldbank.org/data/views/variableselection/selectvariables.aspx?source=word-development -indicators».

World Bank (2013b) 'The World Bank, Data 2013'. Available at: «http://data.worldbank.org/».

Wouters, J., Bruyninckx, H., Basu, S. and Schunz, S. (eds) (2012a) The European Union and Multilateral Governance: Assessing EU Participation in United Nations Human Rights and Environmental Fora (Basingstoke: Palgrave Macmillan).

Wouters, J., Wilde, T. de, Defraigne, P. and Defraigne, J.-C. (eds) (2012b) China, the European Union and the Restructuring of Global Governance (Cheltenham: Edward Elgar).

Wunderlich, J.-U. (2012) 'The EU an Actor Sui Generis? A Comparison of EU and ASEAN Actorness'. JCMS, Vol. 50, No. 4, pp. 653-69.

Yuzawa, T. (2012) 'The ASEAN Regional Forum: Challenges and Prospects'. In Stubbs, R. and Beeson, M. (eds). 